DOI 10.2478/auseb-2021-0008

\title{
Environmental Responsiveness and Firm Value: Evidence from Nigeria
}

\author{
Kenny Adedapo SOYEMI, ${ }^{* 1}$ Joel Adeniyi OKEWALE, ${ }^{2}$ \\ Joshua Damilare OLANIYAN ${ }^{3}$ \\ ${ }^{1}$ Department of Accounting, Faculty of Administration \& Management Sciences \\ Olabisi Onabanjo University, PMB 2002, Ago-Iwoye, Nigeria. \\ *Corresponding author - e-mail: kenny_ade.soyemi@oouagoiwoye.edu.ng
}

${ }^{2}$ Department of Accounting, Faculty of Administration \& Management Sciences Olabisi Onabanjo University, PMB 2002, Ago-Iwoye, Nigeria.

E-mail: jaokewale@oouagoiwoye.edu.ng

${ }^{3}$ Department of Accounting, Faculty of Administration \& Management Sciences Olabisi Onabanjo University, PMB 2002, Ago-Iwoye, Nigeria.

E-mail: joshua.olaniyan@oouagoiwoye.edu.ng

\begin{abstract}
This paper examines the effects of environmental responsiveness on firm value in Nigeria and provides an insight into the feasibility of corporate entities engaging with the United Nations' sustainable development agenda, without compromising their wealth creation agenda. Secondary data were gathered from annual reports and audited accounts of 83 quoted non-financial firms for three years covering the period of 2016-2018. Thereafter, a regression analysis using the Ohlson value relevant model for price valuation was done. Results of the empirical analysis confirm the positive influence of value relevance of book values, earnings per share, alongside environmental responsiveness and firm size on the firm value of Nigerian firms, while leverage is inversely related. Remarkably too, firms with higher values tend towards being environmentally responsive. Impliedly, there is an empirical evidence of reverse causality between firm value and environmental responsiveness.
\end{abstract}

Keywords: book value, eco-efficiency, equity, firm value, ISO14001, sustainable development

JEL Classification: M14, G19 


\section{Introduction}

The quest for sustainable business practices has necessitated firms to seek alternatives in improving their operational processes (Bebbington and Unerman, 2018; Boiral and Henri, 2012; Huppes and Ishikawa, 2009; Le Blanc, 2015; Waal and Thijssens, 2019). The industrial and economic development across nations and regions is largely accompanied by harmful environmental degradation (Huppes and Ishikawa, 2009). While regulatory bodies and government institutions are leading the vanguard for sustainability by way of issuing standards and policies, it has become necessary for firms to adjust and comply with the various regulations and policies on environmental management (Moses et al., 2019). In effect, firms are beginning to adopt various manufacturing techniques that will not only improve their processes but will also minimize the ecological impact of their operations. Since firms are now incurring additional costs to reduce their environmental footprints, it becomes necessary to ascertain whether their response to environmental issues by way of investment in environmental-friendly processes and the adoption of green technologies is creating or adding value as expected. Further, the agreement of world leaders to pursue sustainable development through a win-win approach had heightened the alertness of entities to ensure eco-efficient practices (Boons et al., 2013; Schramade, 2017). Particularly, the progress recorded by the United Nations (UN) in the aspect of environmental sustainability has been relatively low as corporate entities still struggle finding the appropriate means to reduce their environmental impact (Bebbington and Unerman, 2018); this arguably may have informed the inclusion of goals 12 (responsible consumption and production) and 13 (climate action) in the United Nations' Sustainability Development Goals (SDGs), which emphasized efficient production and sustainable climate condition respectively. Based on the foregoing, our study focused on the implication of environmental responsiveness ${ }^{1}$ on firm value, particularly as there is disparity in the submissions of scholars as to its effect on corporate entities' earnings and value (Al-Najjar and Anfimiadou, 2012; Dowell et al., 2000; Ingram and Frazier, 2013; Peck and Sinding, 2003; PwC, 2016; Walley and Whitehead, 1994). In specific, we address the following research questions: (1) What is the effect of environmental responsiveness on firm value in Nigeria? (2) What is the prospect of the UN winwin agenda on corporate value in Nigeria? Our study focuses on Nigeria for several reasons. First, the Nigerian economy ranks as one of the most industrialized and largest economies in Africa with a population of over 200 million and a GDP of $\$ 448.12$ billion (The World Bank, 2020). However, despite the growing adoption of sustainable business practices in Africa, the discourse on its effects on corporate earnings is relatively absent in the literature (Iredele et al., 2019; Moses et al., 2020).

1 The terms environmental responsiveness, eco-efficient business practices, and eco-efficiency are used interchangeably in this study. 
Second, while the discussion on eco-efficient practices seems to be thriving in developed economies, less has been done in this context in emerging economies (Iredele et al., 2019; Moses et al., 2020), leaving the policymakers and businesses in this jurisdiction with poor bases for environmental decisions. Consequently, this study extends the scope of previous research (Al-Najjar and Anfimiadou, 2012; Sinkin et al., 2008) by investigating the effect of environmental responsiveness on firm value in developing economies. Applying Ohlson's value relevant model for price valuation, this study provides additional empirical support towards understanding the nexus between environmental responsiveness and corporate value in Nigeria.

Specifically, our study contributes in the following ways. Firstly, it supplements the existing evidence on environmental management on firm value from developing economies (Che-Ahmad and Osazuwa, 2015), with specific focus on Africa, which is yet to be documented in the literature. Secondly, this study - based on our research - is the first to provide an assessment of the UN "win-win" agenda by examining the influence of eco-efficient practices on firm value in the post-2015 development agenda era. This assessment is important in terms of the strategic role of corporate entities in the actualization of the 2030 Agenda (Rosati and Faria, 2018; Scheyvens et al., 2016). Lastly, our study extends the proxies of eco-efficient business practices by including signatories to the UN Global Compact as environmentally responsive firms. Overall, our empirical results show that environmental responsiveness positively affects firm value. First, we affirm that investment in green technology and the adoption of ecofriendly production process do not affect shareholders' wealth negatively, rather they reduce firm exposure to litigation risks and promote environmental friendliness. Second, our findings suggest that if firms truly commit to the sustainable development goals (SDGs), specifically goals 12 (responsible consumption and production) and 13 (climate action), the UN campaign against environmental degradation may be accomplished soonest.

The remaining of the paper is structured as follows: Section 2 is dedicated to literature review, discussing previous studies and the theoretical framework for the present study; Section 3 discusses the methodology, while results and discussions are contained in Section 4. Section 5 is devoted to conclusions and recommendations.

\section{Literature Review}

\section{Review of Previous Studies}

Environmental responsiveness has its origin in the World Business Council for Sustainable Development (WBCSD) 1992 publication titled Changing Course as 
well as in the 1992 Earth Summit. The WBCSD conceptualized environmental responsiveness as a "delivery of competitively priced goods and services that satisfy human needs and bring quality of life while progressively reducing environmental impacts of goods and resource intensity throughout the entire life-cycle to a level at least in line with the Earth's estimated carrying capacity". Sinkin et al. (2008) described it as the management control process that seeks to maximize the effectiveness of business processes while curtailing their footprint on the environment. Huppes and Ishikawa (2005) conceived it as an approach adopted by the management to reduce environmental intensity, improve environmental productivity, and at the same time minimize the costs and creating value. It can be inferred from the above that environmental responsiveness is an aspect of sustainable development that seeks an equilibrium between the economic operations and environmental actions of firms, without any of the two at a disadvantage. For the purposes of this study, we conceptualize environmental responsiveness as the commitment to environmental preservation through the institution of an environmental management system (EMS) and the adoption of environmentally-friendly production techniques.

Although there has been a previous inquiry into environmental activities and firms' financial performance (Cordeiro and Sarkis, 1997), it is not until 1991 that environmental responsiveness began to be viewed as a means of creating value. This view was premised on the statement of the WBCSD that environmental responsiveness is a "management philosophy" that aims to increase profit while minimizing environmental degradation (WBCSD, 2000). As a follow-up to this assertion, several studies (Cormier and Magnan, 2007; Hart and Dowell, 2011; Hassel et al., 2005; Sinkin et al., 2008) have been conducted to test this claim and position it appropriately. However, studies on environmental management and firm value can be classified into two groups, the event studies being the earliest and then the regression analysis studies (Al-Najjar and Anfimiadou, 2012). Prominent among the event studies are Blacconiere and Northcut (1997) and Jacobs et al. (2010); further analyses of these studies reveal uniform findings and suggest that environmental responsiveness positively affects firm value. Nevertheless, the opinion of scholars on the nexus between green practices and economic performance is inconclusive in the research literature. Wagner et al. (2002) argued that the divergent opinions may be attributed to multiple factors, which include: small sample size and paucity of sound theoretical underpinnings. A relatable example is the inconsistency of authors in the operationalization of firms' environmental responsiveness. In the category of regression analysis studies reporting positive impact is the study of Sinkin et al. (2008) that considers eco-efficiency and firm value using a sample of fortune 500 companies. The study considers an entity to be eco-friendly based on two criteria: an IS0 14001 certification and the publication of Corporate Environmental Report (CER) or sustainability reports at least in the past five years. The study adopts Ohlson's (1995) value relevance model to test the 
authors' hypothesis; results show that firms with eco-efficient business strategies valued more than those without eco-efficient strategies. Similar to this study is the study of Al-Najjar and Anfimiadou (2012), examining the relationship between environmental policies and corporate value in the United Kingdom for the period of 1999-2008. The study, however, broadens the definition of environmental responsiveness of firms by considering not only the ISO 14001 certification and CER publication as criteria but also including indexation in the Business in Environment (BiE) and FTSE $_{4}$ Good directories. These organizations have the reputation of indexing businesses with high environmental performance; hence, firms indexed in their directories are considered to be environmentally responsive. Following the model of Sinkin et al. (2008) in testing the hypothesis, the result shows that eco-friendly firms' prices are higher than of those lacking environmental strategies. While the above statements may have originated from developed economies, Che-Ahmad and Osazuwa (2015) test the same hypothesis as in Al-Najjar and Anfimiadou (2012), using a sample of Malaysian firms and adopting the same methodology; the result of the study is consistent with the former one. Using Swedish listed firms, Hassel et al. (2005) also report that environmental information is value relevant since it is has the likelihood of affecting the expected future profits of quoted companies. Providing evidence from Indonesia, Safitri and Gamayuni (2019) examined the effect of the relationship between research and development (R\&D) investment and environmental investment on eco-efficiency and firm value; results show that R\&D investment has a positive significant correlation with ecoefficiency and corporate value. While these studies may have provided a good insight into the nexus between eco-efficiency and corporate value, the validity of their assertions has been criticized, especially when entities have the tendencies to greenwash stakeholders by mentioning only favourable environmental impacts in their corporate environmental reports or sustainability reports, and, on the other hand, holding an ISO 14001 certification may be a matter of institutional pressure and not necessarily legitimacy (Phan and Baird, 2015).

There are studies with similar findings to those of Al-Najjar and Anfimiadou (2012) and Sinkin et al. (2008). However, they differ with respect to proxies adopted to measure corporate environmental responsiveness. In their study on Dutch firms, Guenster et al. (2011) examined the economic value of corporate eco-efficiency. Covering the period from 1997 to 2004, the study identified eco-efficient firms by using a robust database of corporate-level eco-efficiency index developed by a third party (Innovest Strategic Value Advisors). The authors questioned the appropriateness of this third-party directory due to its comprehensiveness, especially as it had obtained information from more than 20 sources, both quantitative and qualitative, and because of its inclusion of both ex-post (historical) and ex-ante (future) attributes of corporate eco-efficiency. Despite the author's argument as to the robustness of the measure, the major drawback is its low 
acceptability in the empirical literature. Other studies have also considered the level of GHG emission in assessing the environmental consciousness of corporate entities (Pogutz and Russo, 2009).

Another cohort of studies has also examined the impact of environmental responsiveness on other variables such as firm performance, stock returns, and firm growth. Using a survey research design, Hojnik et al. (2017) inquired into ecoinnovation and firm efficiency in Slovenia. The study categorized eco-innovation into three variants, namely: process eco-innovation, product eco-innovation, and organizational eco-innovation; the sample was also classified into more innovative and less innovative organizations. The hypothesis testing result shows that process eco-innovations which involve the use of cleaner production and low energy consumption positively affect firm efficiency. Providing evidence from 28 European countries, Jové-Llopis and Segarra-Blasco (2018) examined the effect of eco-efficiency actions on SMEs growth. Findings suggest that not all eco-business strategies translate to firm growth, especially in the short term. However, the study noted that firms with cleaner production processes perform better. While most of these studies report a positive relationship between ecoefficiency and corporate value, findings may not be generalized, especially in countries like Nigeria, where corporate entities' compliance with environmental policies is low and minimal (Moses et al. 2019), which is coupled with critics' statement (Walley and Whitehead, 1994) that engagement with environmental concerns leads to higher operating costs for the entities. Further, the majority of these studies are conducted before the UN SDGs launch in 2015 and mostly in developed economies. Hence, to bridge these existing gaps, this study focuses on investigating environmental responsiveness and firm value in the Nigerian context.

\section{Theoretical Framework and Hypothesis Development}

This study anchors on the propositions of Resource-Based Theory (RBT) and Legitimacy Theory (LT). The resource-based theory argues that an organization can achieve competitive advantage if it employs resources that are difficult to imitate by its competitors. As argued by Hart and Dowell (2011), using resources that can prevent pollution, reduce the required input, and simplify the production process can increase efficiency, reduce compliance costs and liabilities, and ultimately facilitate competitive advantage. The argument explains why investment in green technology may positively drive corporate earnings and value. The legitimacy theory (LT) further provides insight into why corporate entities adopt green practices. The theory posits that in order for an organization to continue to operate it must act in accordance with the society's values and norms (Dowling and Pfeffer, 1975). Since the relationship between a firm and the society yields mutual benefits, it has been argued that the willingness of an entity to disclose its corporate environmental 
reports can be influenced by both internal and external advantages (Hassel et al., 2005). At the internal level, businesses can take advantage of minimized material costs and top-quality products. Externally, environmentally responsive entities may profit from government regulations on the environment as well as from better access to capital. Porter and Van Der Linde (1995) and Spicer (1978) posit that eco-efficient business strategies can enhance business reputation and increase stakeholders' trust in the firm, which may positively affect the perception of the firm in the financial markets. Further, the previous findings of studies from other climes suggest that eco-responsive entities have a higher market value than those that are not eco-responsive (Al-Najjar and Anfimiadou, 2012; Che-Ahmad and Osazuwa, 2015; Guenster et al., 2011; Sinkin et al., 2008). Based on the foregoing discussion, the study tests the following hypothesis:

$\boldsymbol{H}_{\boldsymbol{o}}$ : The adoption of eco-efficient business strategies is positively correlated to firm value.

\section{Methodology}

\section{Population and Selection of Sample}

The population for this study consists of 105 non-financial firms (excluding financial sector firms) listed on the Nigeria Stock Exchange (NSE) as at 31 December 2018. Of these, 87 firms made up the initial sample size, having published and made available their annual reports and having audited accounts for three years (2016-2018). This period was selected in order to strictly account for the post-2015 United Nations win-win sustainable development agenda. However, four firms namely MTN, Global Spectrum, Medview, and Notore - were later dropped as they were quoted between years 2016 and 2017, whence they did not have market share prices for the selected years. This brings down the final sample size for the study to 83 firms, representing $79 \%$ of the total population. A sample selection procedure of this nature, where selected firms span across the 12 sectors, based on the new NSE classification, that is, stratified (with each sector used as a stratum) random sampling, is believed to eliminate the incidence of selectivity bias among firms. Previous studies suggest that firms listed in the capital market are likely to be the avant-garde in the adoption of cutting-edge environmentally-friendly processes and policies (Hassel et al., 2005; Sinkin et al., 2008).

For the purpose of gathering data for environmental responsiveness (ER), the study adopts the criteria of Sinkin et al. (2008), that is, only firms with an ISO 14001 certification and published Corporate Environmental Reports 
(CERs) or sustainability reports, at least for the past five years, are categorized as environmentally responsive firms. These criteria were premised on the wide recognition of ISO 14001 and environmental reports as a reflection of corporate adoption of green practices (Cormier and Magnan, 2007; Sinclair and Walton, 2003). However, to incorporate responses to the United Nation's concern for environmental protection and to satisfy the need to provide a glimpse of how corporate involvement in environmental protection actions affects firm value, the study further classifies firms that are signatories to the United Nations Global Compact (UNGC) as environmentally responsive. The UNGC is a voluntary United Nations treaty to encourage entities across the globe to embrace sustainable and socially responsible policies and to report on their implementation. It is a principlebased model for commercial enterprises, highlighting ten principles in the areas of human rights, labour, the ecosystem, and anti-corruption. The UNGC has over 13,000 signatories and other stakeholders in over 170 countries. A key focus of the UNGC and its signatories includes supporting actions towards the actualization of the SDGs (UNGC, 2020).

\section{The Research Model}

The study adopts the value relevance model (Ohlson, 1995) as modified by Sinkin et al. (2008) in examining how eco-efficiency influences firm value. The basic model is expressed in equation 1.

$$
P_{i t}=a_{0}+a_{1} B V_{i t}+a_{2} E P S_{i t}+\beta_{0} V+\mu_{i t}
$$

According to the basic Ohlson (1995) model, other information is value relevant if they provide information regarding future earnings. Specifically, if such information is positively associated and significantly related with future earnings, then it adds to the market value of the firm. Accordingly, Sinkin et al. (2008) extended the model by introducing eco-responsiveness (ER) as an additional variable since it provides information that could assist in explaining increased future earnings. For the purposes of this study, the following control variables were added: leverage, return on assets, and firm size. Hence, our final model is as shown in equation 2.

$$
\begin{aligned}
P_{i t}= & a_{0}+a_{1} B V_{i t}+a_{2} E P S_{i t}+\beta_{1} E R_{i t}+\beta_{2} L E V_{i t}+\beta_{2} R O A_{i t}+ \\
& +\beta_{3} S I Z E_{i t}+\mu_{i t}
\end{aligned}
$$


where $\mathrm{P}_{\mathrm{it}}$ is market price of firm $\mathrm{i}$ at date $\mathrm{t}, \alpha_{0}$ is the constant variable, $\mathrm{BV}_{\mathrm{it}}$ represents the book value of equity per share at time $t$, while $\mathrm{ER}_{\mathrm{it}}$ is the environmental responsiveness indicator. $\mathrm{EPS}_{\mathrm{it}}$ is the earnings per share for period $(t-1, t)$, and $\mathrm{LEV}_{\mathrm{it}}$ represents long-term debt to total assets ratio. $\mathrm{ROA}_{\mathrm{it}}$ is return on assets measured as net income/total assets. SIZE $\mathrm{i}_{\mathrm{it}}$ is firm size, measured as natural logarithm of total assets, and, lastly, $\mu_{i t}$ is the error term.

The variable of interest $(E R)$ is a binary variable that assumes the value of 1 for environmentally responsive firms and is otherwise 0 . Besides, the natural logarithm of the dependent variable was computed in order to reduce its magnitude as well as range.

\section{Results and Discussion}

This section provides results from data gathered and analysed. It is subdivided into descriptive and inferential statistics. Thereafter come discussions by way of connecting past scholarly works with the current study.

\section{Descriptive Statistics}

Table 1. Summary of descriptive statistics

\begin{tabular}{lcccc}
\hline Variables & Mean & $\begin{array}{c}\text { Standard } \\
\text { Deviation }\end{array}$ & Min. & Max. \\
\hline Price & 40.189 & 160.613 & 0.2 & $1,555.99$ \\
\hline Book Value & 9.625 & 17.303 & -10.341 & 93.659 \\
\hline EPS & 2.190 & 14.375 & -79.73 & 171.12 \\
\hline ER & 0.321 & 0.468 & 0 & 1 \\
\hline LEV & 0.794 & 4.018 & -11.4453 & 53.635 \\
\hline ROA & 0.0005 & 0.158 & -0.827 & 0.639 \\
\hline SIZE & $74,900,000$ & $221,000,000$ & 200,859 & $1,720,000,000$ \\
\hline
\end{tabular}

Source: authors' computation using Stata software (2020)

Table 1 presents the summarized descriptive statistics of variables used in this study. The average market price for selected firms is $\$ 40.19$ ranging from $¥ 0.20$ (Chams plc in 2018) to $1,555.99$ (Nestle plc in 2017), with a standard deviation of 160.61 . Consequent upon the large range noticeable in the dependent variable (market price), the natural log was computed for regression purposes to reduce the magnitude of the variable. The book value has a mean value of $\$ 9.63$ with a standard deviation of 17.30 . It ranges from a minimum value of $-\mathrm{N} 10.34$ (John Holt in 2017) to a maximum value 
of $\$ 93.66$ (Mobil/11plc in 2018). The mean of EPS is $\$ 2.19$ ranging from $-\$ 79.73$ to N171.12 (for Seplat plc in 2016 and 2017 respectively), with a standard deviation of 14.37. The variable of interest, that is, environmental responsiveness (ER), has a mean value of 0.32 , indicating that $32 \%$ (27) of the selected firms appear to be eco-friendly, while $68 \%$ (56) are not eco-friendly. This may be a result of the voluntary nature of regulations presently governing environmental practices in Nigeria. In comparison, Nigerian firms are relatively more environmentally friendly than Malaysian firms as $16 \%$ was reported by Che-Ahmad and Osazuwa (2015). Furthermore, the control variables, that is, leverage, ROA, and firm size, display mean values of 0.7940, 0.0005, and $\$ 74.9$ billion respectively. Impliedly, Nigerian firms are highly levered (leverage $=79 \%$ ) but less profitable $(\mathrm{ROA}=0.05 \%)$. This is contrary to Malaysian firms, which are reported to be relatively lowly levered (leverage $=24 \%$ ) but more profitable (ROA $=3.08 \%)$.

\section{Multivariate Analysis}

Correlation Analysis

Table 2. Correlation matrix

\begin{tabular}{llllllll}
\hline Variables & lnMP/sh & $\begin{array}{c}\text { Book } \\
\text { Value }\end{array}$ & EPS & ER & LEV & ROA & SIZE \\
\hline lnMP/sh & 1 & & & & & & \\
\hline $\begin{array}{l}\text { Book } \\
\text { Value }\end{array}$ & 0.369 & 1 & & & & & \\
\hline EPS & 0.523 & 0.241 & 1 & & & & \\
\hline ER & 0.270 & 0.294 & 0.143 & 1 & & & \\
\hline LEV & -0.019 & -0.025 & -0.004 & 0.057 & 1 & \\
\hline ROA & 0.201 & 0.273 & 0.227 & 0.176 & 0.048 & 1 & \\
\hline SIZE & 0.201 & 0.545 & 0.076 & 0.440 & 0.084 & 0.221 & 1 \\
\hline
\end{tabular}

Table 2 presents the correlation matrix for the various variables used in this study. The correlation matrix shows the association between the explained variable and the explanatory variables as well as the relationships among explanatory variables. As shown in the table, except for leverage (-0.019), which displays a negative association, all other explanatory variables exhibit positive relationship with firm value (price). In addition, there is no multicollinearity amongst the explanatory variables as none of the correlation values are in excess 
of 0.65 . The maximum is the positive relationship between firm size and book value (0.5451).

The variance inflation factor (VIF) further confirms the assumption of the absence of multicollinearity, as shown in Table 2. Table 3 presents the VIF of the explanatory variables alongside values for their reciprocals (tolerance error).

Table 3. Variance inflation factor (VIF)

\begin{tabular}{lll}
\hline Variables & VIF & $\mathbf{1 / V I F}$ \\
\hline LnTA & 1.67 & 0.5985 \\
\hline Book Value & 1.57 & 0.6377 \\
\hline ER & 1.29 & 0.7757 \\
\hline ROA & 1.10 & 0.9097 \\
\hline EPS & 1.06 & 0.9444 \\
\hline LEV & 1.01 & 0.9897 \\
\hline Mean VIF & 1.28 & \\
\hline
\end{tabular}

Source: authors' computation using Stata software (2020)

As shown in Table 3, the mean of VIF is 1.28, while individual values for each of the predictor variables range from a minimum of 1.01 (leverage) to a maximum value of 1.67 (lnTA). There is none that is greater than 2.50 (rule of thumb for weaker models) and 10.00 (rule of thumb for strong models). In addition, the reciprocals of VIF for all variables are all close to 1.

\section{Regression Analysis}

Table 4 presents the multivariate regression analysis from the estimation of the model specified for the study. It comprises the pooled, fixed, and random effects alongside values for adjusted $\mathrm{R}^{2}$ and results of formal comparison tests used to determine the appropriate model for this study. The Breusch and Pagan Langrangian multiplier (L-M) test (48.02) compares regression estimates of pooled and random effects, while the Hausman test (16.18) compares regression estimates of fixed effects with that of random effects. While the p-value for the former is significant ( $p<0.05)$, the $p$-value for the latter is non-significant $(p>0.05)$. Therefore, both tests support the random effects as the appropriate model for this study; hence, it becomes the basis the study is hinged upon. This is not surprising as data inspection depicts large cross-sectional units (large ' $i$ ') and a small time dimension (small ' $t$ ') indicative of a random effects method as the preferred and expected option. 


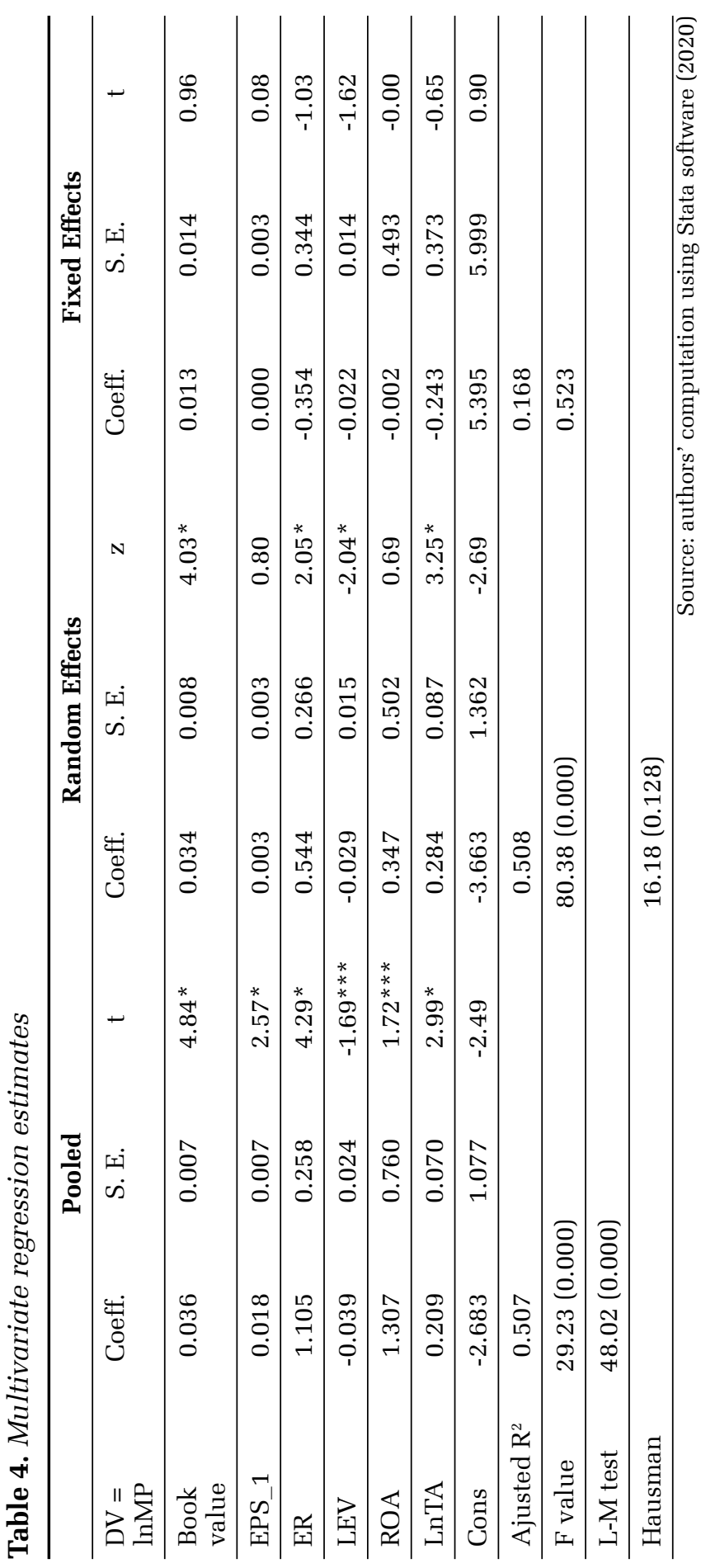


The adjusted $\mathrm{R}^{2}$ is in $51 \%$ implying that the totality of explanatory variables account for $51 \%$ of the variations in the firm value (market price per share) of Nigerian firms, while the F-value is 80.38 with a p-value of $0.0000(\mathrm{p}<0.05)$, indicating that the model is statistically significant. Furthermore, except for leverage (LEV), all other independent variables exhibit positive influence on firm value. Specifically, book value $(t=4.03, p<0.05)$, environmental responsiveness $(t=2.05, p<0.05)$, and firm size $(\mathrm{t}=3.25, \mathrm{p}<0.05)$ display positive and significant relationship, while leverage shows a negative and statistically significant $(t=-2.04, p<0.05)$ association with market price. This implies that the higher the book value, the more environmentally friendly and the larger a firm appears, the higher the market value, while the higher the debt ratio by Nigerian firms, the less the market value. Consequently, book values, investment in environment-related activities, and assets are value relevant in the market valuation of Nigerian firms. Although the lag of EPS (EPS_1) also appears to show positive influence, it is statistically insignificant $(t=0.80, p>0.05)$.

\section{Heteroscedasticity Test and Sensitivity Analysis}

(a) Heteroscedasticity Test

Table 5. The Breusch-Pagan/Cook-Weisberg test for heteroscedasticity

\begin{tabular}{lc}
\hline Hypothesis, $\mathbf{H}_{\mathbf{0}}$ & Constant variance \\
\hline Variables: & Fitted values of lnMP \\
\hline $\mathrm{Chi}^{2}(1)$ & 2.14 \\
\hline $\mathrm{Prob}>\mathrm{Chi}^{2}$ & 0.1431 \\
\hline & Source: authors' computation using Stata software (2020)
\end{tabular}

Homoscedasticity, otherwise known as constant variance, is a major assumption and condition to be satisfied during regression analysis. This study conducts such test using the Breusch-Pagan/Cook-Weisberg test for heteroscedasticity. The results are presented in Table 5. As can be seen in the table, the Breusch-Pagan/ Cook-Weisberg test for heteroscedasticity has an average value of 2.14 with a $\mathrm{p}$-value of 0.1431. Judging from these values, the null hypothesis is not rejected, while the alternative hypothesis is not accepted as the $\mathrm{p}$-value $(\mathrm{p}>0.05)$ appears insignificant, and hence there is constant variance. Therefore, there is an absence of heteroscedasticity as far as this study is concerned.

(b) Sensitivity Analysis

As a robustness check and sensitivity analysis, a robust random effects model was estimated; estimates are as shown in Table 6. Overall, the estimates reflect that, as 
shown in Table 4, except for the lag of EPS (EPS_1), which was hitherto positive but insignificant ( $t=0.80, p>0.01$ ), the lag of EPS (EPS_1) is now positive and significant $(\mathrm{t}=2.55, \mathrm{p}<0.01)$. Similarly, the environmental responsiveness variable (ER) becomes insignificant but still positive $(\mathrm{t}=1.42, \mathrm{p}>0.01)$. The adjusted $\mathrm{R}^{2}$, which was $0.5088(51 \%)$, remains unchanged.

Table 6. Random-effects GLS regression estimates (robust)

\begin{tabular}{lccc}
\hline DV = lnMP/sh & Coeff. & $\begin{array}{c}\text { Robust Std. Error } \\
\text { (RSE) }\end{array}$ & Z \\
\hline Book value & 0.0342 & 0.0089 & $3.84^{*}$ \\
\hline EPS_1 & 0.0025 & 0.0010 & $2.55^{*}$ \\
\hline ER & 0.5439 & 0.3837 & 1.42 \\
\hline LEV & -0.0295 & 0.0066 & $-4.46^{*}$ \\
\hline ROA & 0.3477 & 0.3850 & 0.90 \\
\hline LnTA & 0.2844 & 0.1177 & $2.42^{*}$ \\
\hline Cons & -3.6628 & 1.8401 & -1.99 \\
\hline Ajusted R & 0.5088 & & \\
\hline Wald chi2 (6) & $108.73(0.0000)$ & & \\
\hline
\end{tabular}

Source: authors' computation using Stata software (2020)

\section{Further Empirical Analysis: Endogeneity and Reverse Causality}

Arising from the possibilities of the above regression estimates, from being biased against the problem of endogeneity among explanatory variables as well as the incident of reverse causality, where firm value may also influence environmental responsiveness, and vice versa, this section provides results of two-stage least squares regression in Table 7, which was adopted to address these two problems. The Hausman test (chi2 $(6)=0.23, \mathrm{p}>$ chi $2=0.9998$ ) supports two-stage least squares regression as opposed to the three-stage least squares regression.

The two-stage least squares regression estimates, as shown in Table 7, clearly indicate that environmental responsiveness significantly and positively influences firm value, even after controlling for endogeneity. This result further lends credence to the above estimates, as reported in Table 4. Remarkably too, firms with higher values tend towards being environmentally responsive. Impliedly, there is empirical evidence of reverse causality between firm value and environmental responsiveness. Though not the real focus of this paper, but this later result of reverse causality is plausible as high-valued Nigerian firms are environmentally responsive. A large chunk of existing literature is yet to consider this area; hence these findings obtained from empirical analysis and pointing to the existence of 
reverse causality between firm value and environmental responsiveness appear to be a wake-up call to scholars, especially from emerging nations, to inquire more into this two-way relationship.

Table 7. Two-stage least squares regression estimates

\begin{tabular}{lcccccc}
\hline $\begin{array}{l}\text { Dependent } \\
\text { variables }\end{array}$ & \multicolumn{3}{l}{ lnMP } & & & \multicolumn{2}{c}{ ER } \\
\hline & Coeff. & S. E. & $\mathrm{t}$ & Coeff. & S. E. & $\mathrm{t}$ \\
\hline Book value & 0.0279 & 0.0167 & $1.67^{* * *}$ & -0.0032 & 0.0035 & -0.92 \\
\hline EPS_1 & 0.0372 & 0.0254 & $1.47^{* * *}$ & 0.0006 & 0.0055 & 0.11 \\
\hline ER/lnMP & 4.5767 & 1.2957 & $3.53^{*}$ & 0.1064 & 0.0400 & $2.67^{*}$ \\
\hline LEV & -0.0346 & 0.0661 & -0.52 & 0.0013 & 0.0135 & 0.10 \\
\hline ROA & 0.4475 & 3.6612 & 0.12 & -0.3968 & 0.7245 & -0.55 \\
\hline LnTA & -0.1463 & 0.2322 & -0.63 & 0.0826 & 0.0368 & $2.25^{*}$ \\
\hline Cons & 1.6813 & 3.3789 & 0.50 & -1.0829 & 0.5631 & $-1.92^{*}$ \\
\hline
\end{tabular}

Source: authors' computation using Stata software (2020)

\section{Discussion of Findings}

Based on a sample of 83 quoted non-financial firms in Nigeria, this study provides an empirical insight into the nexus between eco-responsiveness and firm value in the post-2015 sustainable development agenda era. Overall, results show that environmental responsiveness positively affects firm value. Firstly, our findings resonate with Ohlson's (1995) model, which posits that an information is value relevant provided it enhances corporate future profits. Accordingly, we observed that firm value is positively affected by the variable ER, implying that firms investing in eco-friendly equipment and minimizing their operational impact on the environment can increase their future value more than those that are not environmentally responsive. These observations are consistent with the findings of Al-Najjar and Anfimiadou (2012), Che-Ahmad and Osazuwa (2015), Derwall et al. (2005), Guenster et al. (2011), and Sinkin et al. (2008), who also investigated the effects of eco-business strategies on firm value in the US, the UK, and Malaysia. Further, and similar to extant literature, the study controlled for profitability (ROA) and leverage in the extended Ohlson's (1995) value relevance model. Results show that profitability has a positive but insignificant relationship with firm value, which is a slight departure from the outcome of Che-Ahmad and Osazuwa (2015), who reported a positive but significant relationship between the control variable and firm value. Nevertheless, the results confirm the negative 
influence of leverage on firm value. This is also consistent with findings by AlNajjar and Anfimiadou (2012), Che-Ahmad and Osazuwa (2015), and Sinkin et al. (2008). Evidence provided by these results also support the argument of Dowell et al. (2000) and Peck and Sinding (2003) that there is a likelihood of firms' increase in value as well as of reducing their risk profile when they adopt eco-friendly policies.

Extending the scope of our findings, our result provides a glimpse into the prospect of the United Nations' win-win agenda, which is to ensure the profitability of firms on the one hand and the protection of the environment on the other. We interpret the positive relationship between environmental responsiveness and firm value to be an indication that corporate involvement in environmental protection does not hamper shareholders' value but rather ensures a levelled playing ground between corporate activities and physical environment. This position corroborates the argument of Peck and Sinding (2003). Thus, we argue that if firms truly commit themselves to sustainable development goals (SDGs), specifically goals 12 (responsible consumption and production) and 13 (climate action), the UN campaign against environmental degradation may be accomplished soonest. This observation is also in agreement with the predictions of Bebbington and Unerman (2018) and Moses et al. (2019).

Lastly, our findings also unveil some environmental management practices concerning particularly the level of corporate commitment to green practices. As shown in Table 1, the mean value of environmental responsiveness (ER) stood at $32 \%$, indicating that only 27 firms in our sample are environmentally responsive. This resonates weakly with environmental laws and regulation in Nigeria and shows the apathy of corporate entities towards compliance. This observation also aligns with the findings of Iredele et al. (2019) and Moses et al. (2019), who conducted an appraisal of the environmental laws and regulations in Nigeria.

\section{Conclusions and Recommendations}

Our study seeks to establish the nexus between environmental responsiveness and firm value in Nigeria. This was intended to extend the existing literature on eco-efficient business practices (Al-Najjar and Anfimiadou, 2012; Che-Ahmad and Osazuwa, 2015; Sinkin et al., 2008) and to provide extant evidence from emerging economies such as Nigeria. Further, we have attempted to take a glimpse into the prospect of the United Nations' win-win agenda by including firms who are signatories to the UN Global compact as environmentally responsive; this inclusion stands for a novel contribution of our study in the operationalization of environmental responsiveness. Our findings reveal that environmental responsiveness positively affects firms' value. 
The outcome of this study has implications for both corporate managers and national policymakers. At the corporate level, the positive relationship between environmental responsiveness and firm value is an indicator for corporate managers that investment in green technology and the adoption of eco-friendly production processes do not have an adverse effect on shareholders' wealth, rather they reduce firm exposure to litigation risk on the one hand and promote environmental friendliness on the other. Hence, it does not account for any conflict of interest but rather it creates an avenue to achieve a competitive advantage since stakeholders are becoming interested in corporate environmental practices (Bui et al., 2019). At the national level, our findings exposed the weakness in corporate environmental laws and entities' apathy towards compliance. We therefore recommend that the government should revisit the various regulations on environmental protection and ensure strict implementation and compliance.

As with most studies, this study also has its inherent limitations. First, it is the sample size: though encompassing the majority of the firms (79\%) listed on the Nigerian stock exchange, it excludes those in the financial sector, hence limiting findings of this study to all firms quoted on the NSE. In addition, our operationalization of ecoefficiency may not suffice to account for corporate involvement in environmental protection activities. Hence, we encourage future studies to explore these areas, perhaps by exploring other measures of environmental responsiveness.

\section{References}

Al-Najjar, B.; Anfimiadou, A. (2012). Environmental policies and firm value. Business Strategy and the Environment 21: 49-59. https://doi.org/DOI: 10.1002/ bse.713.

Bebbington, J.; Unerman, J. (2018). Achieving the United Nations Sustainable Development Goals: An enabling role for accounting research. Accounting, Auditing \& Accountability Journal 31(1): 2-24.

Blacconiere, W. G.; Northcut, W. D. (1997). Environmental information and market reactions to environmental legislation. Journal of Accounting, Auditing $\mathcal{\sigma}$ Finance 12(2).

Boiral, O.; Henri, J. (2012). Modelling the impact of ISO 14001 on environmental performance : A comparative approach. Journal of Environmental Management 99: 84-97. https://doi.org/10.1016/j.jenvman.2012.01.007.

Boons, F.; Montalvo, C.; Quist, J.; Wagner, M. (2013). Sustainable innovation, business models and economic performance: An overview. Journal of Cleaner Production 45: 1-8. https://doi.org/10.1016/j.jclepro.2012.08.013. 
Bui, B.; Moses, O.; Houqe, M. N. (2019). Carbon disclosure, emission intensity and cost of equity capital: Multi-country evidence. Accounting $\&$ Finance 60(1): 47-71. https://doi.org/10.1111/acfi.12492.

Che-Ahmad, A.; Osazuwa, N. P. (2015). Eco-efficiency and firm value of Malaysian firms. International Journal of Managerial and Financial Accounting 7(3-4): 235-245.

Cordeiro, J. J.; Sarkis, J. (1997). Environmental proactivism and firm performance: Evidence from security analyst earnings forecasts. Business Strategy and the Environment 6: 104-114.

Cormier, D.; Magnan, M. (2007). The revisited contribution of environmental reporting to investors' valuation of a firm's earnings: An international perspective. Ecological Economics 62: 613-626. https://doi.org/10.1016/j.ecolecon.2006.07.030.

Derwall, J.; Guenster, N.; Bauer, R.; Koedijk, K. (2005). The premium puzzle. Journal of Financial Analysts 61(2): 51-63. http://www.jstor.org/stable/4480656.

Dowell, G.; Hart, S.; Yeung, B. (2000). Do corporate global environmental standards create or destroy market value? Management Science 46(8): 1059-1074. https:// doi.org/10.1287/mnsc.46.8.1059.12030.

Dowling, J.; Pfeffer, J. (1975). Organizational legitimacy: Social values and organizational behaviour. The Pacific Sociological Review 18(1): 122-136. https://doi.org/https://doi.org/10.2307\%2F1388226.

Guenster, N.; Bauer, R.; Koedijk, K. (2011). The economic value of corporate eco-efficiency. European Financial Management 17(4): 679-704. https://doi. org/10.1111/j.1468-036X.2009.00532.x.

Hart, S. L.; Dowell, G. (2011). A natural-resource-based view of the firm: Fifteen years after. Journal of Management 37(5): 1464-1479. https://doi. org/10.1177/0149206310390219.

Hassel, L.; Nilsson, H.; Nyquist, S. (2005). The value relevance of environmental performance. European Accounting Review 14(1): 41-61. https://doi.org/10.1080 /0963818042000279722.

Hojnik, J.; Ruzzier, M.; Manolova, T. (2017). Eco-innovation and firm efficiency: Empirical evidence from Slovenia. Foresight and STI Governance 11(3): 103111. https://doi.org/10.17323/2500-2597.2017.3.103.111.

Huppes, G.; Ishikawa, M. (2005). A framework for quantified eco-efficiency analysis. Journal of Industrial Ecology 9(4): 25-41.

(2009). Eco-efficiency guiding micro-level actions towards sustainability: Ten basic steps for analysis. Ecological Economics 68(6): 1687-1700. https://doi. org/10.1016/j.ecolecon.2009.01.007.

Ingram, R. W.; Frazier, K. B. (2013). Environmental performance and corporate disclosure. Journal of Accounting Research 18(2): 614-622.

Iredele, O. O.; Tankiso, M.; Adelowotan, M. O. (2019). The influence of institutional isomorphism and organisational factors on environmental management 
accounting practices of listed Nigerian and South African firms. South African Journal of Accounting Research 34(3): 1-22. https://doi.org/10.1080/10291954. 2019.1675254.

Jacobs, B. W.; Singhal, V. R.; Subramanian, R. (2010). An empirical investigation of environmental performance and the market value of the firm. Journal of Operations Management 28(5): 430-441. https://doi.org/10.1016/j.jom.2010.01.001.

Jové-Llopis, E.; Segarra-Blasco, A. (2018). Eco-efficiency actions and firm growth in European SMEs. Sustainability 10(1): 281. https://doi.org/10.3390/su10010281.

Le Blanc, D. (2015). Towards integration at last? The sustainable development goals as a network of targets. Sustainable Development 23(3): 176-187. https:// doi.org/10.1002/sd.1582.

Moses, O., Michael, E. E.; Dabel-Moses, J. N. (2019). A review of environmental management and reporting regulations in Nigeria. Advances in Environmental Accounting \& Management 8: 159-182. https://doi.org/10.1108/S1479359820190000008007.

Moses, O.; Mohaimen, F. J.; Emmanuel, M. (2020). A meta-review of SEAJ: The past and projections for 2020 and beyond. Social and Environmental Accountability Journal 40(1): 1-18. https://doi.org/10.1080/0969160X.2020.1730213.

Ohlson, J. A. (1995). Earnings, book value, and dividends in equity valuation. Contemporary Accounting Research 11(2): 661-687.

Peck, P.; Sinding, K. (2003). Environmental and social disclosure and data richness in the mining industry. Business Strategy and the Environment 12: 131-146. https://doi.org/DOI: 10.1002/bse.358.

Phan, T. N.; Baird, K. (2015). The comprehensiveness of environmental management systems: The influence of institutional pressures and the impact on environmental performance. Journal of Environmental Management 160: 45-56. https://doi. org/10.1016/j.jenvman.2015.06.006.

Pogutz, S.; Russo, A. (2009). Eco-efficiency vs eco-effectiveness exploring the link between ghg emissions and firm performance. https://doi.org/10.5465/ ambpp.2009.44263752.

Porter, M. E.; Van Der Linde, C. (1995). Toward a new conception of the environmentcompetitiveness relationship. The Journal of Economic Perspectives 9(4): 97118. http://www.jstor.org/stable/2138392.

PwC, P. (2016). Engaging with the sustainable development goals. In: Make it your business: Engaging with the sustainable development goals (December). https:// www.pwc.com/gx/en/sustainability/SDG/SDG Research_FINAL.pdf.

Rosati, F.; Faria, L. G. D. (2018). Addressing the sustainable development goals in sustainability reports: The relationship with institutional factors. Journal of Cleaner Production 215: 1312-1326. https://doi.org/10.1016/j. jclepro.2018.12.107. 
Safitri, V. A. D.; Gamayuni, L. R. R. (2019). Research and development (R\&D), environmental investments, to eco-efficiency and firm value. The Indonesia Journal of Accounting Research 22(3): 355-374.

Scheyvens, R.; Banks, G.; Hughes, E. (2016). The private sector and the SDGs: The need to move beyond 'business as usual'. Sustainable Development 24(6): 371-382. https://doi.org/10.1002/sd.1623.

Schramade, W. (2017). Investing in the UN sustainable development goals: Opportunities for companies and investors. Journal of Applied Corporate Finance 29(2): 87-99. https://doi.org/10.1111/jacf.12236.

Sinclair, P.; Walton, J. (2003). Environmental reporting within the forest and paper industry. Business Strategy and the Environment 12(5): 326-337. https://doi. org/https://doi.org/10.1002/bse.376.

Sinkin, C.; Wright, C. J.; Burnett, R. D. (2008). Eco-efficiency and firm value. Journal of Accounting and Public Policy 27: 167-176. https://doi.org/10.1016/j. jaccpubpol.2008.01.003.

Spicer, B. H. (1978). Investors, corporate social performance and information disclosure: An empirical study. The Accounting Review 53(1): 94-111. http:// www.jstor.org/stable/245728.

The World Bank. (2020). World development indicators.

Waal, J. W. H. van der; Thijssens, T. (2019). Corporate involvement in sustainable development goals: Exploring the territory. Journal of Cleaner Production 119625. https://doi.org/10.1016/j.jclepro.2019.119625.

Wagner, M.; Nguyen, V. P.; Azomahou, T. (2002). The relationship between the environment and economic performance of firms: An empirical analysis of the European paper industry. Corporate Social Responsibility and Environmental Management 9: 133-146. https://doi.org/https://doi.org/10.1002/csr.22.

Walley, N.; Whitehead, B. (1994). It's not easy being green. Harvard Business Review. https://hbr.org/1994/05/its-not-easy-being-green. 


\section{Appendices}

Appendix 1. List of firms used in the study alongside industry classification (final sample)

\begin{tabular}{|c|c|c|}
\hline S/No & Name of Firm & Industry \\
\hline 1 & 11 Plc (formerly Mobil) & Oil \& Gas \\
\hline 2 & ABC Transport & Services \\
\hline 3 & Academy Press & Services \\
\hline 4 & Afromedia & Services \\
\hline 5 & $\begin{array}{l}\text { Aluminium Extrusion } \\
\text { Industries }\end{array}$ & Industrial Goods \\
\hline 6 & Anino International & Oil \& Gas \\
\hline 7 & Ardova (Formerly Forte Oil) & Oil \& Gas \\
\hline 8 & Austin Laz \& Company & Industrial Goods \\
\hline 9 & Berger Paints & Industrial Goods \\
\hline 10 & Beta Glass Co & Industrial Goods \\
\hline 11 & BOC Gases Nigeria & Industrial Goods \\
\hline 12 & C \& I Leasing & Services \\
\hline 13 & Cadbury Nigeria & Consumer Goods \\
\hline 14 & CAP & Industrial Goods \\
\hline 15 & Champion Breweries & Consumer Goods \\
\hline 16 & Chams & ICT \\
\hline 17 & Chellarams & Conglomerates \\
\hline 18 & Conoil & Oil \& Gas \\
\hline 19 & $\begin{array}{l}\text { Courteville Business } \\
\text { Solutions }\end{array}$ & ICT \\
\hline 20 & Cutix & Industrial Goods \\
\hline 21 & CWG & ICT \\
\hline 22 & Daar Communications & Services \\
\hline 23 & Dangote Cement & Industrial Goods \\
\hline 24 & Dangote Sugar Refinery & Consumer Goods \\
\hline 25 & Ekocorp & Healthcare \\
\hline 26 & Ellah Lakes & Agriculture \\
\hline 27 & Eterna & Oil \& Gas \\
\hline 28 & E-Tranzact International & ICT \\
\hline
\end{tabular}




\begin{tabular}{|c|c|c|}
\hline S/No & Name of Firm & Industry \\
\hline 29 & Fidson Healthcare & Healthcare \\
\hline 30 & Flour Mills Of Nigeria & Consumer Goods \\
\hline 31 & FTN Cocoa Processors & Agriculture \\
\hline 32 & GlaxoSmithKline Nigeria & Healthcare \\
\hline 33 & Greif Nigeria & Industrial Goods \\
\hline 34 & Guinness & Consumer Goods \\
\hline 35 & Honeywell Flour Mill & Consumer Goods \\
\hline 36 & Ikeja Hotel & Services \\
\hline 37 & Interlinked Technologies & Services \\
\hline 38 & International Breweries & Consumer Goods \\
\hline 39 & $\begin{array}{l}\text { Japaul Oil \& Maritime } \\
\text { Services }\end{array}$ & Oil \& Gas \\
\hline 40 & John Holt & Conglomerates \\
\hline 41 & Julius Berger Nigeria & Building Construction \\
\hline 42 & Lafarge Africa & Industrial Goods \\
\hline 43 & Learn Africa & Services \\
\hline 44 & Livestock Feeds & Agriculture \\
\hline 45 & May \& Baker Nigeria & Healthcare \\
\hline 46 & McNichols & Consumer Goods \\
\hline 47 & Meyer & Industrial Goods \\
\hline 48 & Morison Industries & Healthcare \\
\hline 49 & MRS Oil Nigeria & Oil \& Gas \\
\hline 50 & $\begin{array}{l}\text { Multiverse Mining and } \\
\text { Exploration }\end{array}$ & Industrial Goods \\
\hline 51 & Nascon Allied Industries & Consumer Goods \\
\hline 52 & NCR (Nigeria) & ICT \\
\hline 53 & $\begin{array}{l}\text { Neimeth International } \\
\text { Pharmaceuticals }\end{array}$ & Healthcare \\
\hline 54 & Nestle Nigeria & Consumer Goods \\
\hline 55 & Nigerian Aviation Handling & Services \\
\hline 56 & Nigerian Breweries & Consumer Goods \\
\hline 57 & Nigerian Enamelware & Consumer Goods \\
\hline 58 & Northern Nigeria Flour Mills & Consumer Goods \\
\hline 59 & Oando & Oil \& Gas \\
\hline
\end{tabular}




\begin{tabular}{|c|c|c|}
\hline S/No & Name of Firm & Industry \\
\hline 60 & Omatek Ventures & ICT \\
\hline 61 & Pharma-Deko & Healthcare \\
\hline 62 & $\begin{array}{l}\text { Portland Paints \& Products } \\
\text { Nigeria }\end{array}$ & Industrial Goods \\
\hline 63 & Premier Paints & Industrial Goods \\
\hline 64 & Presco & Agriculture \\
\hline 65 & PZ Cussons Nigeria & Consumer Goods \\
\hline 66 & R T Briscoe & Services \\
\hline 67 & Rak Unity Petroleum & Oil \& Gas \\
\hline 68 & Red Star Express & Services \\
\hline 69 & SCOA Nigeria & Conglomerates \\
\hline 70 & $\begin{array}{l}\text { Seplat Petroleum } \\
\text { Development }\end{array}$ & Oil \& Gas \\
\hline 71 & Studio Press (Nigeria) & Services \\
\hline 72 & Tantalizers & Services \\
\hline 73 & Initiates & Services \\
\hline 74 & Thomas Wyatt Nigeria & Industrial Goods \\
\hline 75 & Total Nigeria & Oil \& Gas \\
\hline 76 & Tourist Company Of Nigeria & Services \\
\hline 77 & Transcorp Hotels & Services \\
\hline 78 & Trans-Nationwide Express & Services \\
\hline 79 & UAC of Nigeria & Conglomerates \\
\hline 80 & Unilever Nigeria & Consumer Goods \\
\hline 81 & $\begin{array}{l}\text { Union Diagnostic \& Clinical } \\
\text { Services }\end{array}$ & Healthcare \\
\hline 82 & University Press & Services \\
\hline 83 & Vitafoam Nigeria & Consumer Goods \\
\hline
\end{tabular}

